\title{
Economic Evaluation of Methyl Bromide Alternatives for the Production of Tomatoes in North Carolina
}

\author{
Olha Sydorovych ${ }^{1,5,11}$, Charles D. Safley ${ }^{1,6}$, Rob M. Welker ${ }^{2,7}$, \\ Lisa M. Ferguson ${ }^{3,8}$, David W. Monks ${ }^{4,6}$, Katie Jennings ${ }^{4,9}$, \\ Jim Driver ${ }^{2,7}$, and Frank J. Louws ${ }^{2,10}$
}

ADDITIONAL INDEX WORDs. cost of production, partial budget analysis, fumigation, Solanum lycopersicum

Summary. Partial budget analysis was used to evaluate soil treatment alternatives to methyl bromide ( $\mathrm{MeBr}$ ) based on their efficacy and cost-effectiveness in the production of tomato (Solanum lycopersicum). The analysis was conducted for the mountain tomato production region based on 6 years of field test data collected in Fletcher, NC. Fumigation alternatives evaluated included $61.1 \% 1,3$-dichloropropene $+34.7 \%$ chloropicrin (Telone-C35 ${ }^{\mathrm{TM}}$ ), $60.8 \%$ 1,3-dichloropropene $+33.3 \%$ chloropicrin (InLine), 99\% chloropicrin (Chlor-o-pic), 94\% chloropicrin (TriClor EC), $42 \%$ metam sodium (4.26 lb/gal a.i., Vapam), and $50 \%$ iodomethane $+50 \%$ chloropicrin (Midas). The MeBr formulation was $67 \%$ methyl bromide and $33 \%$ chloropicrin (Terr-O-Gas). Chloropicrin applied at 15 gal/acre provided the greatest returns with an additional return of $\$ 907 /$ acre relative to $\mathrm{MeBr}$. Telone-C35 provided an additional return of $\$ 848 /$ acre and drip-applied metam sodium provided an additional return of $\$ 137 /$ acre. The return associated with broadcast applied metam sodium was about equal to the estimated return a grower would receive when applying $\mathrm{MeBr}$. Fumigating with a combination of chloropicrin and metam sodium; shank-applied chloropicrin at $8 \mathrm{gal} /$ acre; drip-applied chloropicrin, Midas, or InLine; and the nonfumigated soil treatment all resulted in projected losses of $\$ 156 /$ acre, $\$ 233$ /acre, $\$ 422$ /acre, $\$ 425 /$ acre, $\$ 604$ /acre, and $\$ 2133$ /acre, respectively, relative to $\mathrm{MeBr}$. Although technical issues currently associated with some of the $\mathrm{MeBr}$ alternatives may exist, results indicate that there are economically feasible fumigation alternatives to $\mathrm{MeBr}$ for production of tomatoes in North Carolina.

$\mathrm{M}$ ethyl bromide is a highly effective broad-spectrum fumigant used extensively to control a wide variety of soilborne

\footnotetext{
Mention of a trademark, proprietary product, or vendor does not constitute a guarantee or warranty of the product and does not imply its approval to the exclusion of other products or vendors that also may be suitable.

This research was funded by the competitive grants program of USDA CSREES 2004-51102-02227 and 2002-51102-01926

${ }^{1}$ Department of Agricultural and Resource Economics, North Carolina State University, Raleigh, NC 27695-8109

${ }^{2}$ Department of Plant Pathology, North Carolina State University, Raleigh, NC 27695-7616

${ }^{3}$ U.S. Department of Agriculture-APHIS-PPQCPHST-Plant Epidemiology and Risk Analysis Laboratory, Raleigh, NC 27606

${ }^{4}$ Department of Horticultural Science, North Carolina State University, Raleigh, NC 27695-7609

${ }^{5}$ Postdoctoral Research Associate.

${ }^{6}$ Professor

${ }^{7}$ Project Coordinator.

${ }^{8}$ Risk Analyst, Former Project Coordinator.

${ }^{9}$ Research Assistant Professor.

${ }^{10}$ Associate Professor.

${ }^{11}$ Corresponding author. E-mail: obsydoro@ncsu.edu.
}

pests in U.S. agriculture. Under the Montreal Protocol of 1991, $\mathrm{MeBr}$ was defined as a chemical that contributes to the depletion of the stratospheric ozone layer, and the amount of $\mathrm{MeBr}$ produced and imported in the United States was incrementally reduced until the phaseout took effect 1 Jan. 2005, except for emergency and critical use exemptions (Osteen, 2003; U.S. Department of Agriculture (USDA), 2008a; U.S. Environmental Protection Agency, 2008). Recent data suggest that the international restrictions on humangenerated sources of bromine slowed down growth in stratospheric ozonedepleting brominated substances (Dorf et al., 2006), and these substances have decreased in the troposphere (Montzka et al., 2003).

An economic analysis conducted by the U.S. Department of Agriculture indicates that the phaseout of $\mathrm{MeBr}$ as a preplant soil fumigant may have substantial impact on many commodities because no known single alternative fumigant, chemical, or other technology exists that can readily substitute for $\mathrm{MeBr}$ in efficacy, cost, ease of use, availability, worker safety, and environmental safety below the ozone layer (Osteen, 2003; USDA, 2008a). Among possible alternatives are host plant resistance, biological control, cultural practices, and alternative chemicals, either alone or in combination (Gullino et al., 2003; Manning and Fennimore, 2001; Martin, 2003; Rieger et al., 2001; Ristaino and Thomas, 1997; Rosskopf et al., 2005; Schneider et al., 2003). A few products that have a long history of use include 1,3-dichloropropene, metam sodium, chloropicrin, and combinations of these [e.g., $61.1 \%$ 1,3-dichloropropene $+34.7 \%$ chloropicrin (Telone-C35 ${ }^{\mathrm{TM}}$; Dow AgroSciences, Indianapolis)] (Duniway, 2002; Martin, 2003; Schneider et al., 2003). The availability of alternative control measures is generally limited because of variations in the target pests, soil types, climates, and state and local regulations.

Fresh market tomatoes were planted on 124,400 acres in the United States in 2007 , with a gross production value of almost $\$ 1300$ million. Southeastern states (Georgia, North Carolina, South Carolina, Tennessee, and Virginia) accounted for about $17 \%$ of the total U.S. tomato

\begin{tabular}{llll}
\hline $\begin{array}{l}\text { Units } \\
\text { To convert U.S. to SI, } \\
\text { multiply by }\end{array}$ & U.S. unit & SI unit & $\begin{array}{l}\text { To convert SI to U.S., } \\
\text { multiply by }\end{array}$ \\
\hline 0.4047 & $\mathrm{acre}(\mathrm{s})$ & $\mathrm{ha}$ & $2.471 \mathrm{l}$ \\
0.3048 & $\mathrm{ft}$ & $\mathrm{m}$ & 3.2808 \\
0.0929 & $\mathrm{ft}^{2}$ & $\mathrm{~m}^{2}$ & 10.7639 \\
9.3540 & $\mathrm{gal} / \mathrm{acre}$ & $\mathrm{L} \cdot \mathrm{ha}^{-1}$ & 0.1069 \\
2.54 & inch(es) & $\mathrm{cm}$ & 0.3937 \\
0.4536 & $\mathrm{lb}$ & $\mathrm{kg}$ & 2.2046 \\
1.1209 & $\mathrm{lb} / \mathrm{acre}$ & $\mathrm{kg} \cdot \mathrm{ha}^{-1}$ & 0.8922 \\
0.1198 & $\mathrm{lb} / \mathrm{gal}$ & $\mathrm{kg} \cdot \mathrm{L}^{-1}$ & 8.3454 \\
0.0254 & $\mathrm{mil}$ & $\mathrm{mm}$ & 39.3701 \\
$\left({ }^{\circ} \mathrm{F}-32\right) \div 1.8$ & ${ }^{\circ} \mathrm{F}$ & ${ }^{\circ} \mathrm{C}$ & $\left(1.8 \times{ }^{\circ} \mathrm{C}\right)+32$
\end{tabular}

Hartecthology · October-December 2008 18(4) 
production (USDA, 2008b). Tomatoes also accounted for $25 \%$ of the United States preplant use of $\mathrm{MeBr}$ in 1997. Therefore, tomato growers are one of the groups impacted by the new $\mathrm{MeBr}$ regulations (Osteen, 2003; Santos et al., 2006).

A series of $\mathrm{MeBr}$ alternative trials conducted at the Mountain Horticultural Crops Research Station in Fletcher, NC, documented the efficacy of alternative fumigants in an annual plasticulture tomato production system (Louws et al., 2004, 2006; Welker et al., 2005a, 2005b, 2007). Fletcher is in western North Carolina (lat. $35^{\circ} 25^{\prime} 36.5^{\prime \prime} \mathrm{N}$, long. $\left.82^{\circ} 33^{\prime} 25.53^{\prime \prime} \mathrm{W}\right)$ and is typical of the Appalachian tomato production region, which includes northern Georgia, western South Carolina, eastern Tennessee, and southwestern Virginia. Documented soilborne pathogens at this site include verticillium wilt (Verticillium dabliae race 1 and race 2), pith necrosis (Pseudomonas corrugata), Pythium spp., and damping off and root rot (Rhizoctonia spp.). Verticillium dabliae race 2 is the most common and most serious soilborne pathogen within this production region and at the Fletcher research station. Weed species primarily included summer annual weeds, such as palmer amaranth (Amaranthus palmeri), common purslane (Portulaca oleracea), goosegrass (Eleusine indica), florida pusley (Richardia scabra), carpetweed (Mollugo verticillata), prickly sida (Sida spinosa), and crowfootgrass (Dactyloctenium aegyptium). The tomato cultivar Mountain Fresh was planted in all trials except one trial in 2005 and one trial in 2006, when cultivars Amelia and Biltmore were planted, respectively.

These trials were part of a broader study also looking at economically feasible alternatives to $\mathrm{MeBr}$ in production of strawberry (Fragaria $\times$ ananassa) in the southeastern United States (Sydorovych et al., 2006). The summary of the products, application rates, and years of tomato trials are presented in Table 1.

The objective of this report was to analyze the economic feasibility of the chemical alternatives to $\mathrm{MeBr}$ in the plasticulture production of tomatoes in the mountain region of North Carolina. First, we estimated the costs and returns associated with growing,

Table 1. Alternative soil treatments, application rates, and years when the soil treatments were evaluated in tomato production systems at the Fletcher, NC, experimental site from 2001 to 2007.

\begin{tabular}{|c|c|c|}
\hline $\begin{array}{l}\text { Alternative soil } \\
\text { treatment }^{\mathrm{z}}\end{array}$ & Application rate ${ }^{y}$ & Years of treatments ${ }^{x}$ \\
\hline Nonfumigated & & $2001-03,2005-07$ \\
\hline $\mathrm{MeBr}$ & $400 \mathrm{lb} / \mathrm{acre}$ & $2001-03,2005-07$ \\
\hline Telone-C35 & $35 \mathrm{gal} / \mathrm{acre}$ & $2001-03,2005-07$ \\
\hline InLine & $26 \mathrm{gal} / \mathrm{acre}$ & $2001-03,2005-07$ \\
\hline $\begin{array}{l}\text { Metam sodium } \\
\quad(\text { broadcast }+ \text { till })^{\mathrm{w}}\end{array}$ & $75 \mathrm{gal} / \mathrm{acre}$ & $2001-03,2005,2006$ \\
\hline $\begin{array}{l}\text { Metam sodium } \\
\quad(\text { drip applied })\end{array}$ & $75 \mathrm{gal} / \mathrm{acre}$ & $2001-03$ \\
\hline Chloropicrin (low rate) & $8 \mathrm{gal} / \mathrm{acre}$ & $2001,2005,2006$ \\
\hline Chloropicrin (high rate) & $15 \mathrm{gal} / \mathrm{acre}$ & $2001-03$ \\
\hline Chloropicrin EC & $200 \mathrm{lb} / \mathrm{acre}$ & $2001-03$ \\
\hline $\begin{array}{l}\text { Chloropicrin EC, } \\
\text { metam sodium }\end{array}$ & $\begin{array}{r}200 \mathrm{lb} / \mathrm{acre}, \\
75 \mathrm{gal} / \mathrm{acre}\end{array}$ & $2001,2002,2005,2006$ \\
\hline Midas $^{\mathrm{u}}$ & $300 \mathrm{lb} /$ acre & $2003,2005-07$ \\
\hline
\end{tabular}

${ }^{\mathrm{z}} \mathrm{MeBr}$ (67\% methyl bromide $+33 \%$ chloropicrin ), Telone-C35 (61.1\% 1,3-dichloropropene $+34.7 \%$ chloropicrin; Dow AgroSciences, Indianapolis), InLine (60.8\% 1,3-dichloropropene $+33.3 \%$ chloropicrin; Dow AgroSciences), metam sodium [42\% metam sodium (Vapam; Amvac, Newport Beach, CA)], chloropicrin [99\% chloropicrin (Chlor-o-pic; Hendrix and Dail, Greensboro, NC)], chloropicrin EC [94\% chloropicrin (TriClor EC, Hendrix and Dail) ], Midas (50\% iodomethane $+50 \%$ chloropicrin; Arysta Life Science, Cary, NC).

${ }^{y}$ All rates are broadcast rates per $43,560 \mathrm{ft}^{2}\left(4046.9 \mathrm{~m}^{2}\right)$ of treated area; 1 lb/acre=1.1209 kg.ha-1, $\mathrm{l} \mathrm{gal} /$ acre $=9.3540 \mathrm{~L} \cdot \mathrm{ha}^{-1}$.

${ }^{x}$ For nonfumigated, MeBr, Telone-C35, and Midas treatments, data include two trials per year in 2005 and 2006. wApplied as a broadcast treatment to the surface of the preformed bed, immediately rototilled throughout the bed profile, and covered with plastic mulch with a buried drip line.

harvesting, and marketing tomatoes in systems including preplant fumigation with $\mathrm{MeBr}$ in a plasticulture production system. Second, we evaluated the economic feasibility of the alternatives to $\mathrm{MeBr}$ using a partial budget methodology.

\section{Partial budget methodology}

Partial budget analysis was used to evaluate the alternative soil treatments. Partial budget analysis is a standard technique to assess the economics of a change in a farm enterprise (Kay and Edwards, 1994) and is frequently used to estimate the impact of a variety of alternative production techniques when the change involves only part of the production system (Roberts and Swinton, 1996; Warmann, 1995; Wossink and Osmond, 2002). The partial budget technique compares the negative effects of applying a new treatment relative to a base or standard treatment to the positive effects associated with the new treatment relative to the base or standard treatment. Therefore, it requires the consideration of the returns associated with treatments and changes in the structure of the production costs. Aspects of costs and returns that do not change with the treatment relative to the base are not considered in this type of analysis. The typical partial budget analysis follows a seven-point format (Dalsted and Gutierrez, 1992), which includes:

A. Negative effects:

Added costs attributable to the new fumigant

$$
\$
$$

Reduced returns attributable to the new fumigant

$$
\$
$$

Total negative effects attributable to the new fumigant $\$$

B. Positive effects:

Reduced costs attributable to the new fumigant $\$$

Added returns attributable to the new fumigant

$$
\$
$$

Total positive effects attributable to the new fumigant

$$
\$
$$

C. Total effects (additional/reduced revenue)

$\$$

In our analysis, it was assumed that added (reduced) costs for the alternative treatments were incurred if any of the following conditions were true: the alternative treatment resulted in higher/lower fumigation costs, including material, equipment, and labor costs; the alternative treatment resulted in higher/lower yield, and therefore, higher/lower yieldrelated labor and material costs; and/or the alternative treatment 
resulted in additional costs associated with weed control.

\section{Base production model for $\mathrm{MeBr}$ as fumigation treatment}

To accomplish the objective of this study, a cost model for a plasticulture production system was first developed for tomato production using $\mathrm{MeBr}$ as the standard fumigation treatment. Production practices were based on customary management practices recommended by North Carolina State University extension and research horticultural specialists, and practiced by growers (Konsler and Gardner, 1990; Sanders, 2001). The budgets were also reviewed by commercial growers for corroboration. Three growers with different farm sizes were contacted independently. After recommended changes were made, the growers were contacted again for their feedback before summarizing the information. The estimated costs per acre needed to produce and harvest tomatoes using $\mathrm{MeBr}$ as the fumigant are listed in Table 2 .

\section{Assumptions of the base production model}

We assumed that machinery and equipment used in this budget reflect machinery components that can be used for other farming enterprises in addition to growing tomatoes on a typical diversified farm. Therefore, the total machinery expense was adjusted to reflect the portion of costs attributable to tomato production enterprise based on assumptions about typical uses of the machinery on an average farm. It was also assumed that the fumigation and irrigation equipment were used only for tomato production. A drip irrigation system was used for managing soil moisture and fertilizer applications in the field.

Input prices were obtained from local dealers who regularly supply growers. Because land rental rates vary throughout North Carolina, a land charge was not included in the budget. It was assumed that hired employees were paid $\$ 8.80 / \mathrm{h}$ (USDA, 2007). However, the wage rates of $\$ 9.93 / \mathrm{h}$ for hired labor and of $\$ 16.39 / \mathrm{h}$ for the owner/ operator were used in the base production model calculations to account for workers' compensation,

Table 2. Estimated costs needed to produce and harvest tomatoes in North Carolina using the plasticulture production system and fumigating with methyl bromide $(\mathrm{MeBr})$.

\begin{tabular}{|c|c|c|c|c|}
\hline Production operation & $\begin{array}{c}\text { Labor } \\
(\$ / \text { acre })^{z}\end{array}$ & $\begin{array}{c}\text { Machinery } \\
\text { (\$/acre) }\end{array}$ & $\begin{array}{c}\text { Materials } \\
\text { (\$/acre) }\end{array}$ & $\begin{array}{c}\text { Total } \\
\text { (\$/acre) }\end{array}$ \\
\hline \multicolumn{5}{|l|}{ October } \\
\hline \multicolumn{5}{|l|}{ Removal and disposal } \\
\hline Disking & 11.92 & 20.48 & 0.00 & 32.40 \\
\hline Liming & 0.00 & 0.00 & 37.00 & 37.00 \\
\hline \multicolumn{5}{|l|}{ Planting rye (Secale cereale) } \\
\hline for cover crop & 9.93 & 29.71 & 17.00 & 56.64 \\
\hline Total October costs & 212.51 & 134.57 & 54.00 & 401.08 \\
\hline \multicolumn{5}{|l|}{ March } \\
\hline Plowing and disking & 8.94 & 24.34 & 0.00 & 33.28 \\
\hline Subsoiling & 17.87 & 8.15 & 0.00 & 26.02 \\
\hline Total March costs & 26.81 & 32.49 & 0.00 & 59.30 \\
\hline \multicolumn{5}{|l|}{ April } \\
\hline Assembling irrigation system & 119.16 & 1.35 & 0.00 & 120.51 \\
\hline Preplant fumigation with $\mathrm{MeBr}$ & 39.34 & 297.99 & $1,333.00$ & $1,670.33$ \\
\hline Preplant fertilizing & 8.94 & 11.66 & 104.25 & 124.85 \\
\hline Total April costs & 167.44 & 311.00 & $1,437.25$ & $1,915.69$ \\
\hline \multicolumn{5}{|l|}{ May } \\
\hline Purchase and transplant plugs & 57.59 & 10.45 & 385.00 & 453.04 \\
\hline Irrigate and fertilize plugs & 9.93 & 0.84 & 0.83 & 11.60 \\
\hline Replant plugs $2 \%$ & 9.93 & 0.00 & 7.70 & 17.63 \\
\hline Drip irrigation (31 2-h applications) & 615.66 & 320.04 & 0.00 & 935.70 \\
\hline Fertilizing & 0.00 & 0.00 & 188.69 & 188.69 \\
\hline String (two applications) & 34.80 & 0.00 & 9.90 & 44.70 \\
\hline Pruning & 47.85 & 0.00 & 0.00 & 47.85 \\
\hline Staking & 52.50 & 0.00 & 550.00 & 602.50 \\
\hline Weekly pesticide sprays & 26.22 & 72.71 & 241.24 & 340.17 \\
\hline Postemergence herbicides & 6.55 & 8.78 & 34.38 & 49.71 \\
\hline Total May costs & 861.03 & 412.82 & $1,417.74$ & $2,691.59$ \\
\hline \multicolumn{5}{|l|}{ June } \\
\hline Drip irrigation (30 2-h applications) & 595.80 & 309.72 & 0.00 & 905.52 \\
\hline Fertilizing & 0.00 & 0.00 & 182.64 & 182.64 \\
\hline Weekly pesticide sprays & 26.22 & 72.71 & 307.21 & 406.14 \\
\hline Postemergence herbicides & 6.55 & 8.78 & 7.88 & 23.21 \\
\hline Total June costs & 628.57 & 391.21 & 497.73 & $1,517.51$ \\
\hline \multicolumn{5}{|l|}{ July } \\
\hline Drip irrigation (31 2-h applications) & 615.66 & 320.04 & 0.00 & 935.70 \\
\hline Fertilizing & 0.00 & 0.00 & 188.69 & 188.69 \\
\hline Weekly pesticide sprays & 26.22 & 72.71 & 143.44 & 242.37 \\
\hline Custom harvest & $8,973.84$ & 0.00 & 0.00 & $8,973.84$ \\
\hline Total July costs & $9,615.72$ & 392.75 & 332.13 & $10,340.60$ \\
\hline Total costs & $11,512.08$ & $1,674.84$ & $3,738.85$ & $16,925.77$ \\
\hline $\begin{array}{l}\text { Total production costs } \\
\text { (harvest not included) }\end{array}$ & $2,538.24$ & $1,674.84$ & $3,738.85$ & $7,951.93$ \\
\hline
\end{tabular}

unemployment, FICA taxes, and other overhead expenses, as well as the base wage rate, and were meant to be representative of the "true" costs of labor and not just the base wage rate.

Standard production practices for the region include the use of 5to 8-week-old transplants grown in plug trays in greenhouses that are field set in early May to late June. Plants are grown on 6- to 8-inch raised beds that are 24 to 30 inches wide on 60 -inch centers with a single drip irrigation line buried $\approx 2$ inches deep, and beds are covered with 1 to 1.5 mil of black low-density polyethylene mulch immediately after 
$\mathrm{MeBr}$ soil fumigation. Tomatoes are spaced 18 inches between plants on the center of the bed and are trained using the standard California/Florida stake and weave system. The crop is typically sprayed weekly with fungicides and insecticides depending on local pest populations and recommendations. Fertigation and irrigation is delivered through the drip irrigation line. Tomatoes are harvested by hand at the "vine ripe" stage, when color begins to develop, from four to eight or more times per crop, every 3 to $7 \mathrm{~d}$. Fruit are washed and field packed, or managed through a packing house, where they are typically treated with a surface sterilant and sorted for size and color.

In this study, we assume that tomatoes were harvested in July (early to midseason crop) by custom labor. Tomato harvest was graded in four fruit size categories (minimum diameter $\times$ maximum diameter in inches): jumbo and extra large (jumbo $=3 \times 3$ $10 / 16$, extra large $=2-14 / 16 \times 3-6 /$ 16), large $(2-11 / 16 \times 3-3 / 16)$, medium and small (medium $=2-8$ / $16 \times 2-14 / 16$, small $=2-4 / 16 \times 2$ $10 / 16)$, and culls $[<2-4 / 16$, misshapen, or damaged (catfacing, cracking, insects, diseases, etc.)]. The costs per acre to produce and harvest tomatoes using $\mathrm{MeBr}$ as the fumigant were estimated to be $\$ 16,926 /$ acre (Table 2). Expenses were separated by different months of the growing season. Operations in July were the most expensive, costing an estimated $\$ 10,341 /$ acre, while May was the second most expensive month, costing \$2692/acre. April operations totaled \$1916/acre, June operations totaled $\$ 1518 /$ acre, October operations totaled \$401/ acre, and March operations totaled $\$ 59 /$ acre. Overall, materials accounted for $\$ 3739 /$ acre, labor costs made up $\$ 11,512 /$ acre (including $\$ 8974$ /acre paid for custom harvest labor), and the costs linked to owning and operating the equipment totaled $\$ 1675 /$ acre.

\section{Costs of fumigation with $\mathrm{MeBr}$ and alternative soil treatments}

Fumigation treatments varied with respect to the number of years of data (Table 1). All experiments followed a randomized complete block design with four replications per treatment. Fumigated plot lengths were
50 to $100 \mathrm{ft}$ long and the inner center was planted to 12 plants per plot, except in 2005, when 14 plants were planted. The alternative soil treatments evaluated for tomato production were $61.1 \%$ 1,3-dichloropropene $+34.7 \%$ chloropicrin (Telone- $\mathrm{C} 35^{\mathrm{TM}}$ ); 99\% chloropicrin (Chlor-o-pic; Hendrix and Dail, Greensboro, NC); 94\% chloropicrin (TriClor EC; Hendrix and Dail); $60.8 \%$ 1,3-dichloropropene $+33.3 \%$ chloropicrin (InLine ${ }^{\mathrm{TM}}$; Dow AgroSciences); $42 \%$ metam sodium (4.26 lb/gal a.i., Vapam; Amvac, Newport Beach, CA); and 50\% iodomethane + $50 \%$ chloropicrin (Midas ${ }^{\mathrm{TM}}$; Arysta Life Science, Cary, NC). The MeBr formulation was $67 \%$ methyl bromide and $33 \%$ chloropicrin (Terr-O-Gas; Great Lakes Chemical Corp., West Lafayette, IN). Telone-C35, chloropicrin, Midas, and $\mathrm{MeBr}$ were injected into the soil through two shanks at $\approx 12$ inches deep in the 24in-wide beds. Immediately, the drip tape was applied within the bed and low-density polyethylene mulch was pulled over the bed surface. The single-pass fumigation rig was outfitted with a flow meter to verify application rates, and orifice plates were changed for calibrated chemical distribution. InLine, chloropicrin EC (emulsifiable concentrate), and metam sodium were applied with water using two buried drip lines placed equidistant from the edge of the bed and each other. Metam sodium (broadcast + till) was applied as a broadcast treatment to the surface of the preformed bed, immediately rototilled throughout the bed profile, and covered with plastic mulch with a buried drip line as above. For treatments with chloropicrin followed by metam sodium, chloropicrin was drip or shank applied into the beds and metam sodium was drip-applied $7 \mathrm{~d}$ later. All procedures were done when soils were at $60 \%$ to $80 \%$ field capacity and above $55{ }^{\circ} \mathrm{F}$. Tomatoes were planted a minimum of $21 \mathrm{~d}$ after the last fumigant application. Crop phytotoxicity was not observed in any trial. In addition, a nonfumigated control was evaluated to determine the economic necessity of fumigation and to verify the presence of soilborne pest pressure (Louws et al., 2004, 2006; Welker et al., 2005a, 2005b, 2007).

Estimated fumigation costs varied depending on the soil treatment
(Table 3). The projected fumigation costs associated with $\mathrm{MeBr}$ were $\$ 1670 /$ acre. Fumigation with Midas resulted in increased costs of fumigation relative to $\mathrm{MeBr}(\$ 2220$ / acre). The remaining soil treatment alternatives resulted in savings in the costs of fumigation relative to $\mathrm{MeBr}$. The nonfumigated alternative was the least expensive soil treatment option with the cost estimate of $\$ 870 /$ acre, which included the estimates of equipment, material, and labor costs associated with laying the drip tape and plastic mulch. The estimated reduced fumigation costs per acre for each alternative relative to $\mathrm{MeBr}$ are listed in the last column of the table. The cost difference ranged from an additional $\$ 550 /$ acre for Midas to a cost saving of $\$ 651 /$ acre for chloropicrin applied at a low rate. The cost of nonfumigated treatment was $\$ 800 /$ acre lower than the cost of fumigating with $\mathrm{MeBr}$.

\section{Estimated yields associated with $\mathrm{MeBr}$ and alternative soil treatments}

Tomatoes were sorted into four grades: jumbo and extra large, large, medium and small, and culls. Marketable yield included jumbo, extra large, large, medium, and small grades. To control for possible variation in yield across years, yield data in each marketable grade category were normalized to the average tomato yield in the same grade category for $\mathrm{MeBr}$ plots that were obtained in the same year, similar to previously published work (Sydorovych et al., 2006). For example, if the $\mathrm{MeBr}$ yield in grade 1 , year 1 was $20,000 \mathrm{lb} /$ acre, this was considered $100 \%$ yield in this category. If alternative fumigant " $\mathrm{A}$ " had a yield of $23,000 \mathrm{lb} /$ acre in the same grade this yield was considered $115 \%$. In year 2, if the yield for $\mathrm{MeBr}$ was $25,000 \mathrm{lb} /$ acre $(100 \%)$ and the yield for alternative "A" was $20,000 \mathrm{lb} /$ acre, this was considered an $80 \%$ yield. The yields for $\mathrm{MeBr}$ in each grade were averaged across all years (e.g., $22,500 \mathrm{lb} /$ acre), and the average relative yields for the alternative were calculated [e.g., $(115 \%+80 \%) \div 2=$ 97.5\%]. The overall average relative yield for alternative " $\mathrm{A}$ " in grade 1 would then be the product of the average $\mathrm{MeBr}$ yield in this category and the average relative yield of 
Table 3. Estimated tomato fumigation costs for methyl bromide (MeBr) and selected alternative soil treatments and the fumigation costs of the alternative treatments relative to $\mathrm{MeBr}$.

\begin{tabular}{|c|c|c|c|c|c|}
\hline $\begin{array}{l}\text { MeBr and selected } \\
\text { alternative soil } \\
\text { treatments } \\
\end{array}$ & $\begin{array}{c}\text { Fumigation } \\
\text { labor costs } \\
(\$ / \text { acre })^{\mathrm{y}}\end{array}$ & $\begin{array}{c}\text { Fumigation } \\
\text { machinery costs } \\
(\$ / \text { acre })\end{array}$ & $\begin{array}{c}\text { Fumigation } \\
\text { material costs } \\
(\$ / \text { acre })\end{array}$ & $\begin{array}{c}\text { Total } \\
\text { fumigation costs } \\
(\$ / \text { acre })\end{array}$ & $\begin{array}{c}\text { Fumigation costs } \\
\text { relative to } \mathrm{MeBr} \\
(\$ / \text { acre })\end{array}$ \\
\hline Midas $^{x}$ & 39.34 & 297.99 & $1,883.00$ & $2,220.33$ & +550.00 \\
\hline $\mathrm{MeBr}^{\mathrm{x}}$ & 39.34 & 297.99 & $1,333.00$ & $1,670.33$ & 0.00 \\
\hline $\begin{array}{c}\text { Chloropicrin } \mathrm{EC}^{\mathrm{w}} \text {, } \\
\text { metam sodium }\end{array}$ & 39.34 & 304.71 & $1,242.00$ & $1,586.05$ & -84.28 \\
\hline InLine & 39.34 & 304.71 & $1,036.00$ & $1,380.05$ & -290.28 \\
\hline Chloropicrin $\mathrm{EC}^{\mathrm{w}}$ & 39.34 & 304.71 & $1,002.00$ & $1,346.05$ & -324.28 \\
\hline Metam sodium (drip applied $)^{\mathrm{v}}$ & 39.34 & 304.71 & 977.00 & $1,321.05$ & -349.28 \\
\hline Metam sodium (broadcast + till $)^{\mathrm{x}}$ & 68.84 & 432.42 & 773.00 & $1,274.26$ & -396.07 \\
\hline Telone-C35 & 39.34 & 297.99 & 883.00 & $1,220.33$ & -450.00 \\
\hline $\begin{array}{l}\text { Chloropicrin } \\
{(\text { high rate })^{\mathrm{x}}}^{\text {(high }}\end{array}$ & 39.34 & 297.99 & 813.13 & $1,150.45$ & -519.88 \\
\hline $\begin{array}{l}\text { Chloropicrin } \\
(\text { low rate })^{\mathrm{x}} \\
\text { Nonfumigated }\end{array}$ & $\begin{array}{l}39.34 \\
39.34\end{array}$ & $\begin{array}{l}297.99 \\
297.99\end{array}$ & $\begin{array}{l}682.40 \\
533.00\end{array}$ & $\begin{array}{r}1,019.73 \\
870.33\end{array}$ & $\begin{array}{l}-650.60 \\
-800.00\end{array}$ \\
\hline
\end{tabular}

${ }^{2}$ Midas ( $50 \%$ iodomethane $+50 \%$ chloropicrin; Arysta Life Science, Cary, NC), MeBr (67\% methyl bromide + 33\% chloropicrin), chloropicrin EC [ $94 \%$ chloropicrin (TriClor EC; Hendrix and Dail, Greensboro, NC)], metam sodium [42\% metam sodium (Vapam; Amvac, Newport Beach, CA)], InLine (60.8\% 1,3 -dichloropropene $+33.3 \%$ chloropicrin; Dow AgroSciences, Indianapolis), Telone-C35 (61.1\% 1,3-dichloropropene + 34.7\% chloropicrin; Dow AgroSciences), chloropicrin [99\% chloropicrin (Chloro-pic; Hendrix and Dail)].

y $\$ 1.00 /$ acre $=\$ 2.4711 / \mathrm{ha}$

${ }^{x}$ Beds were preformed and a single row fumigation rig was then drawn to form 24 -inch-wide and 8 -inch-tall beds $(1$ inch $=2.54 \mathrm{~cm})$, inject fumigant 12 inches deep through two knives spaced 10 inches apart, lay drip tape, and pull low-density polyethylene mulch over the beds, all in one pass. This rig was outfitted with a flow meter to verify application rates. Metam sodium was applied to cover preformed beds, rotovated into the upper 8 - to 12 -inch profile, and then drip tape and plastic mulch were immediately applied as above. All procedures were done when soils were at $60 \%$ to $80 \%$ field capacity and above $55{ }^{\circ} \mathrm{F}\left(12.8^{\circ} \mathrm{C}\right)$.

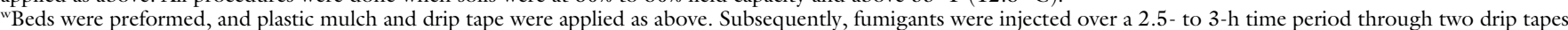
spaced equally across the top of the 24 -inch-wide bed to achieve uniform wetting of the soil within the bed profile.

the alternative in this category (e.g., $22,500 \mathrm{lb} /$ acre $\times 97.5 \%=$ $21,938 \mathrm{lb} /$ acre). This approach circumvented yield variations due to year effects, particularly because all treatments were not included in all years, and normalized all yield data relative to the $\mathrm{MeBr}$ treatment.

Average relative tomato yields for $\mathrm{MeBr}$ and the selected alternative soil treatments at the study site in Fletcher, NC, are reported in Table 4 in jumbo and extra large, large, and medium and small categories. Average marketable yields represent a total yield in all marketable grades. Projected total harvest costs, including harvest materials and labor, and projected yield values associated with estimated yield levels for each alternative are presented in the table as well. The highest average marketable yield $(78,003 \mathrm{lb} /$ acre $)$ was associated with Telone-C35. Chloropicrin applied at a high rate (15 gal/acre) resulted in the average marketable yield of $76,506 \mathrm{lb} /$ acre, closely followed by the combination of chloropicrin and metam sodium $(75,917$ lb/acre), Midas $(75,851 \mathrm{lb} /$ acre $)$, $\mathrm{MeBr}(74,782 \mathrm{lb} /$ acre $)$, metam sodium $\operatorname{EC}(73,376 \mathrm{lb} /$ acre $)$, broadcast-applied metam sodium $(72,554$ lb/acre), chloropicrin applied at low rate $(71,195 \mathrm{lb} /$ acre $)$, InLine $(70,663 \mathrm{lb} /$ acre $)$, and chloropicrin EC $(70,612 \mathrm{lb} /$ acre $)$. The nonfumigated alternative resulted in the considerably lower average marketable yield of $62,621 \mathrm{lb} /$ acre. A harvest charge of $\$ 3.00$ per 25 -lb box was used to estimate total harvest costs for marketable yields. This charge includes harvest-related labor and materials.

The price farmers receive for their tomato fruit varies depending on fruit size. Therefore, yields reported in different fruit size categories were used to calculate projected gross returns to the farmers. It was assumed that farmers received $\$ 9.50$ for $25-\mathrm{lb}$ box of jumbo and extra large tomatoes, $\$ 8.15$ for 25 -lb box of large tomatoes, and $\$ 7.00$ for $25-1 b$ box of medium and small tomatoes, representing seasonal average warehouse prices in western North Carolina in 2007 (USDA, 2008c). We use tomato prices in 2007 as an alternative to the average tomato prices over the period of this study to base our conclusions on the current market conditions, which could be beneficial to the farmers. Likewise, all material and labor costs were based on 2007 values.
$\mathrm{MeBr}$ treatment resulted in the projected yield value of $\$ 25,684$ /acre (Table 4). Telone-C35, chloropicrin applied at the high rate, and Midas alternative treatments resulted in increases in projected yield values relative to $\mathrm{MeBr}$ of $\$ 812 /$ acre, $\$ 621 /$ acre, and $\$ 254 /$ acre, respectively. Reductions in projected gross returns to the farmers relative to $\mathrm{MeBr}$ were observed for the chloropicrin and metam sodium combination treatment (\$104/acre), and drip- and broadcast-applied metam sodium $(\$ 381 /$ acre and $\$ 736 /$ acre, respectively). More substantial losses in gross returns relative to $\mathrm{MeBr}$ were estimated for chloropicrin EC (\$1219/acre), shank-applied chloropicrin at the low rate $(\$ 1287 /$ acre $)$, and InLine (\$1362/acre). The nonfumigated alternative resulted in the greatest loss of projected yield value (\$4365/acre) relative to $\mathrm{MeBr}$.

\section{Partial budget analysis of soil treatment alternatives}

The positive and negative effects for each soil treatment are shown in Table 5. Added/reduced costs of the alternative treatments were calculated using the projected fumigation costs (Table 3) and harvest costs (Table 4) 
Table 4. Average marketable tomato yields for the years of the trials, the harvest-related costs, including labor and materials, gross returns for methyl bromide $(\mathrm{MeBr})$, and selected alternative soil treatments, and the difference in the harvest costs and yield values relative to $\mathrm{MeBr}$.

\begin{tabular}{|c|c|c|c|c|c|c|c|c|}
\hline $\begin{array}{l}\text { MeBr and } \\
\text { selected } \\
\text { alternative soil } \\
\text { treatments }^{\mathrm{z}}\end{array}$ & $\begin{array}{c}\text { Avg } \\
\text { marketable } \\
\text { yields } \\
(1 \mathrm{~b} / \text { acre })^{\mathrm{x}} \\
\end{array}$ & $\begin{array}{c}\text { Jumbo and } \\
\text { extra large } \\
\text { fruit }^{\mathrm{y}} \\
\text { (lb/acre) }\end{array}$ & $\begin{array}{c}\text { Large } \\
\text { fruit }^{\mathrm{y}} \\
\text { (lb/acre) } \\
\end{array}$ & $\begin{array}{l}\text { Medium and } \\
\text { small fruit }^{\mathrm{y}} \\
(\mathrm{lb} / \text { acre })\end{array}$ & $\begin{array}{c}\text { Total } \\
\text { harvest } \\
\text { costs } \\
(\$ / \text { acre })^{x} \\
\end{array}$ & $\begin{array}{c}\text { Harvest } \\
\text { costs relative } \\
\text { to } \mathrm{MeBr} \\
(\$ / \text { acre }) \\
\end{array}$ & $\begin{array}{c}\text { Gross } \\
\text { returns } \\
\text { (\$/acre) } \\
\end{array}$ & $\begin{array}{c}\text { Gross } \\
\text { returns } \\
\text { relative to } \\
\mathrm{MeBr} \\
\text { (\$/acre) } \\
\end{array}$ \\
\hline Telone-C35 & 78,003 & 35,861 & 23,224 & 18,918 & $9,360.36$ & +386.52 & $26,495.24$ & +811.62 \\
\hline \multicolumn{9}{|l|}{ Chloropicrin } \\
\hline (high rate) & 76,506 & 38,570 & 22,298 & 15,638 & $9,180.72$ & +206.88 & $26,304.39$ & +620.76 \\
\hline $\mathrm{MeBr}$ & 74,782 & 37,156 & 22,371 & 15,255 & $8,973.84$ & 0.00 & $25,683.63$ & 0.00 \\
\hline \multicolumn{9}{|l|}{ Chloropicrin } \\
\hline EC, metam sodium & 75,917 & 32,354 & 23,630 & 19,933 & $9,110.04$ & +136.20 & $25,579.14$ & -104.49 \\
\hline \multicolumn{9}{|l|}{ Metam sodium } \\
\hline \multicolumn{9}{|l|}{ Metam sodium } \\
\hline InLine & 70,663 & 35,836 & 20,719 & 14,107 & $8,479.56$ & -494.28 & $24,322.03$ & $-1,361.59$ \\
\hline Nonfumigated & 62,621 & 29,288 & 18,602 & 14,731 & $7,514.52$ & $-1,459.32$ & $21,318.37$ & $-4,365.25$ \\
\hline chloropicrin (TriClor EC; & $\mathrm{x}$ and Dail)], & $\begin{array}{l}\text { am sodium }[4 \\
10 / 16 \text {. }\end{array}$ & metam soc & Vapam; Amv & hloropicrin & )], InLine (6 & $\begin{array}{l}1,3 \text {-dichlor } \\
6, \text { large }=2\end{array}$ & $\begin{array}{l}\text { ix and Dail, } \\
\text { crin EC }[94 \% \\
\text { ene }+33.3 \% \\
16 \times 3-3 / 16 \text {, }\end{array}$ \\
\hline
\end{tabular}

relative to $\mathrm{MeBr}$ associated with alternative soil treatments. In addition, alternative treatments with TeloneC35, InLine, and chloropicrin (EC and shank-applied at high and low application rates), as well as the nonfumigated treatment, resulted in insufficient weed control, and added costs for these treatments also include the additional costs of weed control estimated at $\$ 27.08 /$ acre. This estimate includes labor, materials, and equipment costs associated with one application of $18 \%$ sethoxydim (Poast; BASF Corp., Research Triangle Park, NC) for grass control. Added/reduced returns were based on the projected yield values of the alternative soil treatments presented in Table 4.

Because $\mathrm{MeBr}$ was the standard or base treatment, there are no added costs or reduced returns for this fumigant, and the total effects are zero. The nonfumigated treatment resulted in the greatest negative effects relative to $\mathrm{MeBr}$ with combined added costs and reduced returns estimated at $\$ 4392$ /acre. Fumigation with InLine, the shankapplied low-rate chloropicrin, and the drip-applied chloropicrin resulted in similar negative effects of $\$ 1389 /$ acre, \$1314/acre, and \$1246/acre, respectively. Fumigation with the broadcast-applied metam sodium, Midas, Telone-C35, the drip-applied metam sodium, a combination of chloropicrin and metam sodium, and the shank-applied high-rate chloropicrin resulted in smaller negative effects relative to $\mathrm{MeBr}$ of \$736/acre, \$678/acre, \$414/acre, $\$ 381$ /acre, \$241/acre, and \$234/ acre, respectively. The nonfumigated alternative resulted in the greatest positive effects relative to $\mathrm{MeBr}$ with combined reduced costs and added returns estimated at $\$ 2259 /$ acre. Fumigation with Telone-C35, the shank-applied high-rate and low-rate chloropicrin resulted in total positive returns relative to $\mathrm{MeBr}$ estimated at \$1262/acre, \$1141/acre, \$1081/ acre, respectively. Finally, fumigation with the drip-applied chloropicrin, InLine, broadcast-applied and dripapplied metam sodium, Midas, and the combination of chloropicrin and metam sodium resulted in slightly lower positive effects relative to $\mathrm{MeBr}$, which were estimated at
$\$ 825$ /acre, \$785/acre, \$663/acre, $\$ 518$ /acre, $\$ 254 /$ acre, and $\$ 84 /$ acre, respectively.

The estimated gross returns, total production costs, and net returns for $\mathrm{MeBr}$ and the alternative soil treatments are presented in Table 6 . The net return for each soil treatment is the difference between the projected gross returns and the associated costs that changed as a result of applying different soil treatments (fumigation, harvest, and weed control costs) and other production costs that remained constant regardless of the soil treatment used. For example, the projected gross returns for the $\mathrm{MeBr}$ alternative was $\$ 25,684$ /acre (Table 4 ), while the associated fumigation costs were \$1670/acre (Table 3) and harvest costs were $\$ 8974$ /acre (Table 4). Production costs that did not change as a result of varying the soil treatments were estimated at \$6282/ acre, which was calculated by subtracting the fumigation and harvest costs from the total production costs of $\$ 16,926 /$ acre (Table 2). Soil treatment with $\mathrm{MeBr}$ did not require additional weed control inputs. This procedure yielded an estimated 


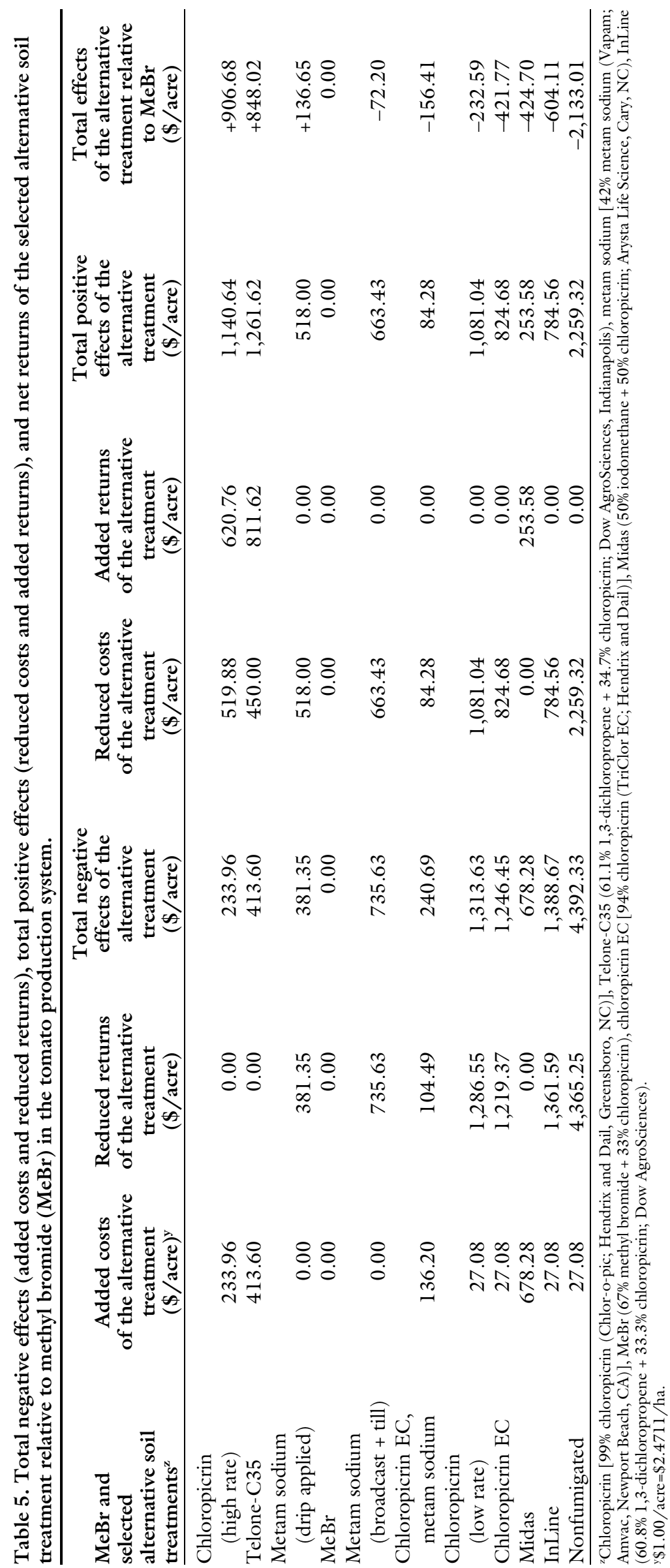

net return, less a land rental rate, of $\$ 8758$ /acre for the $\mathrm{MeBr}$ treatment. The net returns for the other soil treatment alternatives were calculated the same way.

Net returns of the alternative treatments relative to $\mathrm{MeBr}$ are presented in the last columns of Tables 5 and 6 . The tables highlight that economically viable alternatives exist when compared with fumigation with $\mathrm{MeBr}$. The loss of $\$ 2133$ /acre, a $25 \%$ decrease, of net return relative to $\mathrm{MeBr}$ associated with no fumigation also indicates the benefit of fumigation in tomato production. In our tomato trials, Telone-C35 was one of the best-performing alternatives, resulting in an estimated additional net return to the farmers of $\$ 848$ / acre relative to $\mathrm{MeBr}$. Fumigation with metam sodium also showed good results; the drip-applied alternative resulted in an additional net return of $\$ 137$ /acre relative to $\mathrm{MeBr}$, while the broadcast-applied metam sodium resulted in a net return estimate close to the estimate for $\mathrm{MeBr}$ with projected decrease in net return of only $\$ 72 /$ acre relative to $\mathrm{MeBr}$. The results for chloropicrin also indicate that it might be considered as an economically viable alternative, particularly where the primary soilborne pest is $V$. dabliae or other fungi. In fact, chloropicrin applied at the high rate resulted in the highest net return with an additional net return of $\$ 907 /$ acre relative to $\mathrm{MeBr}$. At the same time, drip-applied chloropicrin and the lowrate shank-applied chloropicrin at the low rate showed losses in net returns relative to $\mathrm{MeBr}(\$ 422 / \mathrm{acre}$ and $\$ 233$ /acre, respectively). A combination of chloropicrin and metam sodium showed a loss of net returns of $\$ 156$ relative to $\mathrm{MeBr}$. Fumigation with InLine resulted in a loss of net returns of $\$ 604 /$ acre relative to MeBr. Finally, Midas showed a good performance adding to yield estimates relative to $\mathrm{MeBr}$, but high costs of this product partially offset the yield advantage, resulting in a loss of $\$ 425 /$ acre relative to $\mathrm{MeBr}$. These trials represent earlier work with the Midas 50:50 formulation.

More recent work at Fletcher, NC, has used a reduced rate of Midas (150 lb/acre broadcast) combined with virtually impermeable film (VIF) (F.J. Louws and R.M. Welker, unpublished data). Preliminary data 
from the reduced rate of Midas with VIF suggests that this combination offers similar efficacy as the full rate of Midas but at a reduced cost. Calculations suggest that the reduced rate of fumigant combined with the increased cost of VIF results in a decreased fumigation cost of $\$ 510 /$ acre relative to the high rate under standard plastic mulch. However, additional trials are needed to determine the economic benefits of the reduced rate/VIF combination compared with standard $\mathrm{MeBr}$ treatments.

\section{Discussion}

While these results indicate that there are technically and economically feasible alternatives to $\mathrm{MeBr}$ for tomato production in growing conditions similar to Fletcher, NC, actual costs and returns will vary from grower to grower due to market situation, labor supply, age and condition of equipment, managerial skills, and many other factors. Because every situation is different, it is recommended that every grower estimate their individual production, harvesting, and marketing costs based on their own production techniques, price expectations, local supply of labor, and market situation before selecting an alternative preplant fumigant. The specific conditions of the site are also an important factor.

This site was documented with no nematode problems and relatively low nutsedge [purple nutsedge (Cyperus rotundus) and yellow nutsedge (C. esculentus)] populations. The primary impact of the fumigant was on $V$. dabliae, race 1 and race 2 strains. Tomato cultivars with resistance to $V$. dabliae race 1 were used in all studies. Products such as chloropicrin with high efficacy against soilborne pathogenic fungi were expected to perform well. Field sites with high populations of plant parasitic nematodes, a different spectrum of weeds, especially nutsedge, or a different array of soilborne pathogens would generate different impacts, efficacy, and economic viability values of selected alternatives. Likewise, coarse field soils with a high sand content would not be suitable for effective drip application of fumigants. Finally, all of these trials did not seek to capture the early, and typically higher-priced market. Cold wet soils in the early spring, typical for this production region, would delay 
planting due to the minimum $2 \mathrm{l}-\mathrm{d}$ waiting period requirement after field application before planting, which may result in growers missing a critical market window. Stunting and phytotoxicity has been observed with fumigant combinations that contained Telone-C35 when applied in the early spring under less than ideal conditions (F.J. Louws and R.M. Welker, unpublished data).

Finally, it is necessary to point out that the leading products have been incorporated into large on-farm trials, locally and regionally. All of the trials used to compile this data were done under strict technical conditions, ensuring use of proper and calibrated equipment with due consideration to soil and weather conditions. Commercial farms do not always have the capacity or the adaptability to adjust, and widespread adoption of alternatives has occurred at a slower pace than anticipated. As more on-farm research and demonstrations are conducted, complimented with a combined infrastructure of public and private technical support and extension (Welker et al., 2005a, 2005b), it is anticipated that growers will implement alternative pest management practices on larger acreage, moving toward greater reliance on one or more of the alternatives documented here.

\section{Literature cited}

Dalsted, N.L. and P.H. Gutierrez. 1992. Partial budgeting. Colorado State Univ. Coop. Ext. Rpt. No. 3.760.

Dorf, M., J.H. Butler, A. Butz, C. CamyPeyret, M.P. Chipperfield, L. Kritten, S.A. Montzka, B. Simmes, F. Weidner, and K. Pfeilsticker. 2006. Long-term observations of stratospheric bromine reveal slow down in growth. Geophys. Res. Lett. 33:L24803, doi: 10.1029/2006GL027714.

Duniway, J.M. 2002. Status of chemical alternatives to methyl bromide for preplant fumigation of soil. Phytopathology 92:1337-1343.

Gullino, M.L., A. Camponogara, G. Gasparrini, V. Rizzo, C. Clini, and A. Garibaldi. 2003. Replacing methyl bromide for soil disinfestation: The Italian experience and implications for other countries. Plant Dis. 87:1012-1021.

Kay, R.D. and W.M. Edwards. 1994. Farm management. McGraw-Hill, New York.

Konsler, T.R. and R.G. Gardner. 1990. Commercial production of staked toma- toes in North Carolina. North Carolina Coop. Ext. Serv. Publ. AG-60.

Louws, F.J., L.M. Ferguson, K. Ivors, J. Driver, K. Jennings, D. Milks, P.B. Shoemaker, and D.W. Monks. 2004. Efficacy of methyl bromide alternatives for verticillium and weed management in tomatoes. 8 May 2008. <http://mbao.org/2004/ Proceedings04/043\%20Louws\%20toma to\%202004.pdf>.

Louws, F.J., R.M. Welker, J.G. Driver, K. Jennings, and D.W. Monks. 2006. Efficacy of methyl bromide alternatives for weed and verticillium management in tomatoes. 8 May 2008. <http:// mbao.org/2006/06Proceedings/ 061 Louwsetalweed2006.pdf>.

Manning, G.R. and S.A. Fennimore. 2001. Evaluation of low-rate herbicides to supplement methyl bromide alternative fumigants to control weeds in strawberry. HortTechnology 11:603-609.

Martin, F.N. 2003. Development of alternative strategies for management of soil borne pathogens currently controlled with methyl bromide. Annu. Rev. Phytopathol. 41:325-350.

Montzka, S.A., J.H. Butler, B.D. Hall, D.J. Mondeel, and J.W. Elkins. 2003. A decline in tropospheric organic bromine. Geophys. Res. Lett. 30:1826, doi: $10.1029 / 2003$ GL017745.

Osteen, C. 2003. Methyl bromide phaseout proceeds: Users request exemptions. Amber Waves 1:23-27.

Rieger, M., G. Krewer, and P. Lewis. 2001. Solarization and chemical alternatives to methyl bromide for preplant soil treatment of strawberries. HortTechnology 11:258-264.

Ristaino, J.B. and W. Thomas. 1997. Agriculture, methyl bromide, and the ozone hole: Can we fill the gaps? Plant Dis. 81:964-977.

Roberts, W.S. and S.M. Swinton. 1996. Economic methods for comparing alternative crop production systems: A review of the literature. Amer. J. Alternative Agr. 11:10-17.

Rosskopf, E.N., D.O. Chellemi, N. Kokalis-Burelle, and G.T. Church. 2005. Alternatives to methyl bromide: A Florida perspective. 8 May 2008. <http://www.apsnet.org/online/ feature/methylbromide/ $>$.

Sanders, D.C. 2001. Fresh market tomato production piedmont and coastal plain of North Carolina. North Carolina Coop. Ext. Serv. Publ. HIL-28-A.

Santos, B.M., J.P. Gilreath, T.N. Motis, J.W. Noling, J.P. Jones, and J.A. Norton. 2006. Comparing methyl bromide alter- natives for soilborne disease, nematode and weed management in fresh market tomato. Crop Prot. 25:690-695.

Schneider, S.M., E.N. Rosskopf, J.G. Leesch, D.O. Chellemi, C.T. Bull, and M. Mazzola. 2003. USDA-ARS research on alternatives to methyl bromide: Pre-plant and postharvest. Pest Mgt. Sci. 59:814-826.

Sydorovych, O., C.D. Safley, L.M. Ferguson, E.B. Poling, G.E. Fernandez, F.M. Brannen, D.W. Monks, and F.J. Louws. 2006. Economic evaluation of methyl bromide alternatives for the production of strawberries in the southeastern United States. HortTechnology 16:118-128.

U.S. Department of Agriculture. 2007. Monthly field report, Sep. 2007. 10 Oct. 2007. <http://www.ncagr.com/stats>.

U.S. Department of Agriculture. 2008a. Methyl bromide. Agricultural Research Service. 23 Jan. 2008. <http://www.ars.usda. gov/Research/docs.htm?docid=10408>.

U.S. Department of Agriculture. 2008b. USDA-NASS quick stats. 24 July. 2008 <http://www.nass.usda.gov/>.

U.S. Department of Agriculture. 2008c. Fruit and vegetable market news. 23 Jan. 2008. <http://marketnews.usda.gov/ portal $/ \mathrm{fv}>$.

U.S. Environmental Protection Agency. 2008. The phaseout of methyl bromide. 23 Jan. 2008. <http://www.epa.gov/ ozone/mbr/index.html>

Warmann, G.W. 1995. Economics of liming Kansas cropland: Owner-operator and landlord-tenant considerations. Kansas State Univ. Ext. Publ. MF-2137.

Welker, R.M., J.G. Driver, and F.J. Louws. 2005a. Efficacy of fall and spring applied methyl bromide alternatives in tomatoes. 8 May 2008. <http:// mbao.org/2005/05 Proceedings/ 015WELKERTomatoMBAO2005.pdf>.

Welker, R.M., J.G. Driver, and F.J. Louws. 2005b. Methyl bromide alternatives training for extension agents and growers. 8 May 2008. <http:// mbao.org/2005/05 Proceedings/ 011WELKERtrianingMBAO2005.pdf>.

Welker, R.M., J.G. Driver, J.P. Smith, P.M. Brannen, C.A. Schiemann, and F.J. Louws. 2007. On-farm research to implement MB alternatives: An area wide initiative. 8 May 2008. <http:// $\mathrm{mbao}$.org/2007/Proceedings / 022LOUWSareaWideMBAO07.pdf>.

Wossink, G.A.A. and D.L. Osmond. 2002. Farm economics to support the design and selection of cost-effective BMPs: Nitrogen control in the Neuse River Basin, North Carolina. J. Soil Water Conservation 57:213-220. 